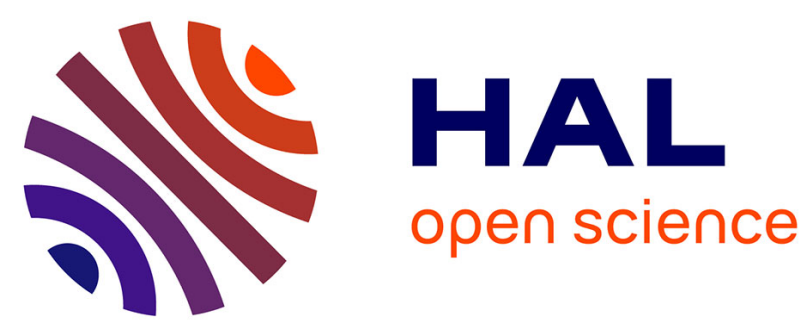

\title{
Variable expressivity of HJV related hemochromatosis: "Juvenile" hemochromatosis?
}

\author{
Houda Hamdi-Roze, Zeineb Ben Ali, Martine Ropert, Lenaick Detivaud, \\ Samira Aggoune, Dominique Simon, Gilles Pelletier, Yves Deugnier, \\ Véronique David, Edouard Bardou-Jacquet
}

\section{To cite this version:}

Houda Hamdi-Roze, Zeineb Ben Ali, Martine Ropert, Lenaick Detivaud, Samira Aggoune, et al.. Variable expressivity of HJV related hemochromatosis: "Juvenile" hemochromatosis?. Blood Cells, Molecules and Diseases, 2019, 74, pp.30-33. 10.1016/j.bcmd.2018.10.006 . hal-01950953

\section{HAL Id: hal-01950953}

\section{https://hal-univ-rennes1.archives-ouvertes.fr/hal-01950953}

Submitted on 13 Dec 2018

HAL is a multi-disciplinary open access archive for the deposit and dissemination of scientific research documents, whether they are published or not. The documents may come from teaching and research institutions in France or abroad, or from public or private research centers.
L'archive ouverte pluridisciplinaire HAL, est destinée au dépôt et à la diffusion de documents scientifiques de niveau recherche, publiés ou non, émanant des établissements d'enseignement et de recherche français ou étrangers, des laboratoires publics ou privés. 
Houda Hamdi-Rozé $(1,2)$ / Zeineb Ben Ali $(1,3)$ / Martine Ropert (1,4) / Lénaïck Detivaud (1)/ Samira Aggoune (5) / Dominique Simon (6) / Gilles Pelletier (7) / Yves Deugnier (1,3) /Véronique David (2) / Edouard Bardou-Jacquet $(1,3)$

1 -Univ Rennes, CHU Rennes, INSERM, French reference center for hemochromatosis and iron metabolism disease, F-35000 Rennes, France

2 - Univ Rennes, CHU Rennes, CNRS, IGDR, UMR 6290, Molecular Genetics Department, F-35000, Rennes, France

3 - Univ Rennes, CHU Rennes, INSERM, Liver Disease Department, F-35000 Rennes, France

4 - Univ Rennes, CHU Rennes, INSERM, Biochemistry Department, F-35000 Rennes, France

5 - EPH Belfort, Pediatric Department, El Harrach, Alger, DZ 16000

6 - Hopital Universitaire Robert-Debré, Endocrinology and Pediatric Diabetology, Paris, FR 75019

7 - Hopital Bicêtre, Hepatogastroenterology, Le Kremlin-Bicêtre, FR 94275

\section{Corresponding Author:}

- Houda Hamdi-Rozé

- Laboratoire de Génétique Moléculaire et Génomique, CHU de Rennes, 2 rue Henri Le Guilloux, Rennes, FR 35033

- $\quad$ Phone +33299282584 Fax : +33299284 112

- Mail : houda.hamdi@chu-rennes.fr

Running Title: Late Juvenile Hemochromatosis 


\section{ABSTRACT}

Juvenile hemochromatosis is a rare autosomal recessive disease due to variants in the Hemojuvelin (HJV) gene. Although biological features mimic HFE hemochromatosis, clinical presentation is worst with massive iron overload diagnosed during childhood.

Our study describes clinical features and results of genetic testing for a group of patients initially referred for a hepcidino-deficiency syndrome and for whom HJV hemochromatosis was finally diagnosed. 662 patients with iron overload and high serum transferrin saturation were tested, and five genes (HFE, HJV, HAMP, TFR2, SLC4OA1) were sequenced.

Among our cohort, ten unrelated patients were diagnosed with HJV hemochromatosis. Genetic testing revealed five previously published and five undescribed variants: p.Arg41Pro, p.His180Arg, p.Lys299Glu, p.Cys361Arg and p.Ala384Val.

Surprisingly, this study revealed a late age of onset in some patients, contrasting with the commonly accepted definition of "juvenile" hemochromatosis. Five of our patients were 30 years old or older, including two very late discoveries. Biological features and severity of iron overload were similar in younger and older patients

Our study brings new insight on HJV hemochromatosis showing that mild phenotype and late onset are possible. Genetic testing for HJV variants should thus be performed for all patients displaying a non-p.Cys282Tyr homozygous HFE hemochromatosis with hepcidin deficiency phenotype. 


\section{INTRODUCTION}

Juvenile hemochromatosis is a rare autosomal recessive disease, known to be responsible for severe iron overload in young patients, due to deleterious variants in the HJV (or HFE2) gene. HJV is located on chromosome 1q and encodes a 426 amino acid protein called hemojuvelin (HJV) (1) which is a bone morphogenic protein 6 (BMP6) co-receptor. Hemojuvelin is a critical regulator of hepcidin expression, acting downstream of HFE or TFR2, which explain the severe phenotype observed in that disease. (2)

Although biological features mimic HFE hemochromatosis (high serum ferritin and serum transferrin saturation), clinical presentation is more severe with massive iron overload associated to cardiomyopathy, $(3,4)$ hypogonadism, diabetes, cirrhosis, and an increased risk of death. $(5,6)$ The p.Gly320Val (c.959 G>T) is the most frequent variant responsible for HJV hemochromatosis, as reported in the first description of Papanikolaou et al. (1) and in many other studies since. (7-10) For now, more than 40 variants in HJV gene have been identified. (11)

The mainstay of the phenotypical presentation is young age at diagnosis, symptoms of iron overload appearing between the first and third decade. (1) Thus it is usually advised to test for HJV pathogenic variants in young patients $(<30)$ with non HFE hemochromatosis. $(12)(13,14)$ However variable expressivity is well described in HFE hemochromatosis, (15) and has been reported in rare form of hemochromatosis (16-18). Regarding HJV, variable age of onset has been suggested in family from Japanese origin that may prompt to test for HJV even in patients older than 30. (19)

This study reports our experience of patients with HJV hemochromatosis, their clinical features and the results of genetic testing. 


\section{PATIENTS AND METHODS}

Hemojuvelin (HJV) variants were screened as part of the diagnosis activity of the French Reference Centre for Rare Genetic Iron Overload Diseases between 2005 and 2016. Genetic testing for HJV was performed in 662 patients with elevated serum ferritin (men $>300 \mu \mathrm{g} / \mathrm{L}$ and women $>200 \mu \mathrm{g} / \mathrm{L}$ ) and/or hepatic iron overload according to liver biopsy or magnetic resonance imaging $(>100 \mu \mathrm{mol} / \mathrm{g})$, associated with high serum transferrin saturation. Patients with HFE p.Cys282Tyr homozygosity were excluded.

Human samples were obtained from the processing of biological samples through the Center for Health Biological Ressources (Centre de Ressources Biologiques Santé - CRB Santé) of Rennes BB0033-00056.There search protocol was conducted under French legal guidelines and fulfilled the requirements of the local institutional ethics committee. All blood samples for biochemical assays and genetic testing were collected prior to any treatment (phlebotomy or chelator).

Serum hepcidin-25 was quantified using a competition CE-marked Enzyme Immunoassay (EIA) kit (S1337; Peninsula Laboratories International, San Carlos, CA, USA) following the instructions of the manufacturer. Serum samples were diluted in supplied standard diluent and analyzed in duplicate at $450 \mathrm{~nm}$ on a microplate reader (Victor ${ }^{\circledR}$-Perkin Elmer Massachusetts USA). Hepcidin concentrations were interpolated from standard curves generated by logistic 4-parameter nonlinear curve fitting. The intra-assay and interassay coefficient of variation was $3.5 \%$ and $6.3 \%$, respectively and the lower quantification limit was $0,01 \mathrm{nmol} / \mathrm{l}$. The reference range for hepcidin concentration in normal subjects was 4 to $30 \mathrm{nmol} / \mathrm{l}$.

Sequencing of the entire coding region and intronic flanking sequences of the HJV gene (NM_213653.3) was carried out. Sanger sequencing was performed until 2013 using the ABI Prism terminator cycle sequencing ready reaction kit and $A B I$ prism 377 DNA sequencer (Applied Biosystems), or the BigDye terminator cycle sequencing kit and 3130 XL Genetic Analyser (Applied Biosystems). Since 2014, next-generation sequencing (NGS) has been performed using the lon AmpliSeq Library Kit 2.0 and Ion PGM 200 Sequencing Kit (LifeTechnologies) following the manufacturer's protocol. Samples were sequenced on the lon Torrent PGM and confirmed by Sanger analysis if a variant was found. To exclude association with variant in other genes involved in iron metabolism, sequencing of the HFE, HAMP, SLC4OA1 and TFR2 coding and intronic flanking regions was performed. Moreover, microcytogenetic rearrangements were searched by multiplex ligation probe amplification (MLPA - MRC-Holland) on the five genes.

The pathogenicity of the newly identified missense variants was estimated according to their frequency in large public genetic databases (Exome Sequencing Project (20), 1000 Genome Project (21), Exome Aggregation Consortium (22)), in silico predictions, and functional and segregation data when available. Classification of already described and newly found variants has been established according to the American College of Medical Genetics and Genomics (ACMG) guidelines. (23)

Written informed consent for genetic analysis was obtained from all subjects or their parents if minors. Family study was offered when a variant was identified. 


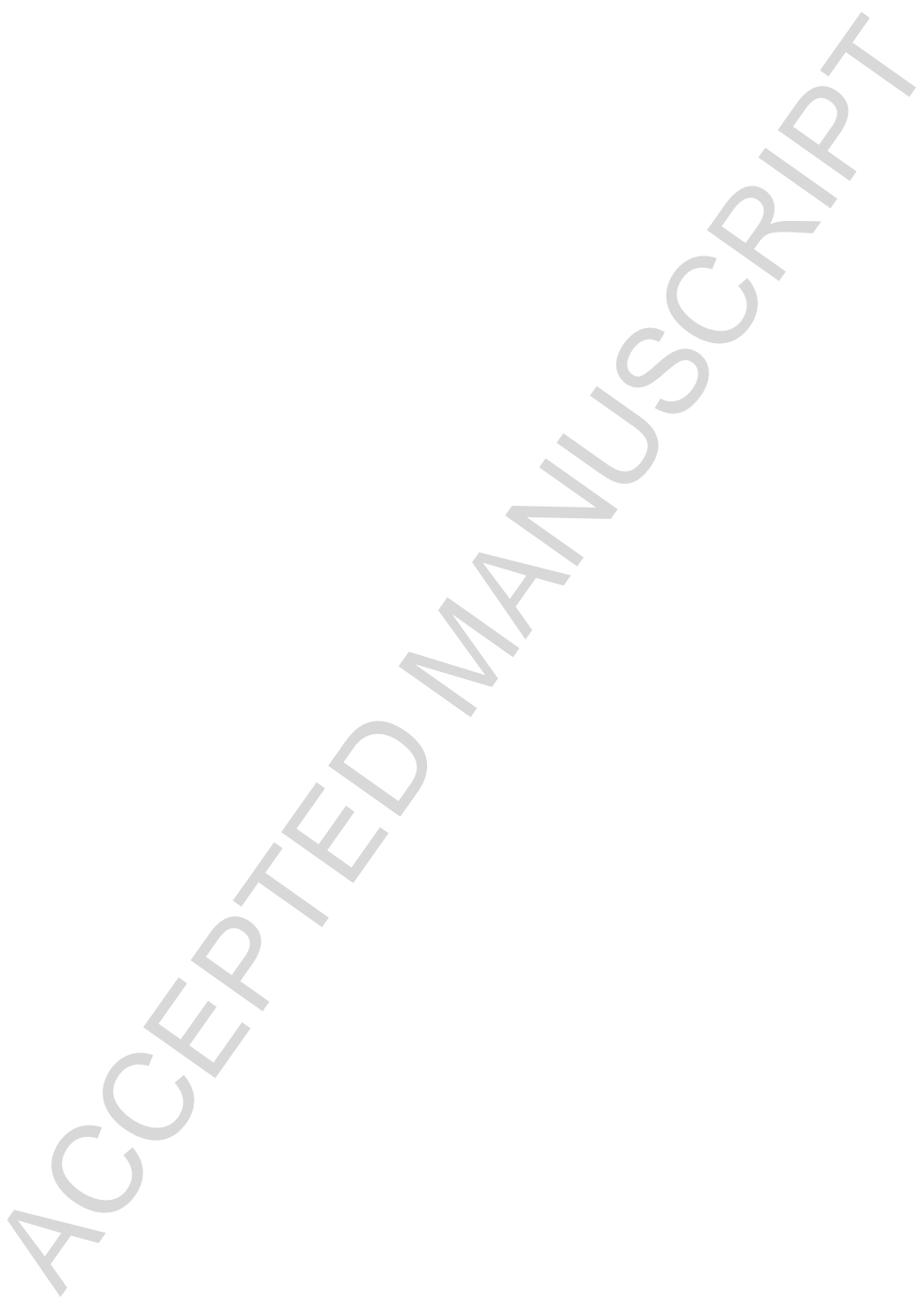




\section{RESULTS}

Between 2005 and 2016, ten unrelated patients were diagnosed with HJV hemochromatosis. Their clinical and biological features are detailed in Table 1.

Genetic testing revealed five previously published variants: p.Gly320Val (c.959 G>T), p.Arg176Cys (c.526C >T), p.Leu101Pro (c.302 T>C), p.Arg385X (c.1153 C>T) and p.Arg288Trp (c.862 C>T) and five unpublished variants: p.Arg41Pro (c.122 G>C), p.Lys299Glu (c.895 A>G), p.His180Arg (c.539 A>G), p.Ala384Val (c.1151 C>T) and p.Cys361Arg (c.1081 T>C). Three patients were homozygous for the p.Gly320Val variant, one was homozygous for $p . A r g 385 X$ and one for the $p$.Arg288Trp variant. Five patients were compound heterozygous: p.Arg41Pro/p.Arg176Cys, p.Leu101Pro/p.Lys299Glu, p.Leu101Pro/p.His180Arg, p.Leu101Pro/p.Ala384Val and p.Gly320Val/p.Cys361Arg. All new variants were found at a heterozygous state associated with a known pathogenic alteration.

Results of pathogenicity classification for these variants are reported in Table 1.

No deleterious variant was found in HAMP, SLC4OA1 and TFR2 for these patients. However, sequencing of HFE revealed a p.Cys282Tyr/p.His63Asp compound heterozygosity in patient 9 and p.Cys282Tyr heterozygosity in patient 10 . The variants identified are distributed all along the protein, without preferential location in one of the domains (Fig. 1).

Family study was available for 6 patients. Patient's 8 brother was homozygous for the p.Arg288Trp variant and had severe hemochromatosis with diabetes diagnosed at the age of 28 . Screening in patient's 5 family uncovered the homozygous p.Arg385X variant in his 6 years old brother before the onset of iron overload or any clinical sign (normal serum transferrin saturation and ferritin). Heterozygosity was found in his parents, who had third degree consanguinity, and in his sister. In patient 2, 3, 6 and 7 who had heterozygous compound variants, family study identified heterozygous subjects for each variant, confirming that variants were situated in trans; all these individuals had normal iron blood tests.

Among this cohort, nine patients underwent phlebotomies which were well tolerated, whereas patient 5 and his brother both received iron chelating agents (deferasirox or deferoxamine), because of local practice habits. The two male patients with hypogonadism (patient 1 and 8) were treated with androgen replacement therapy. 
Among the patients referred for non HFE hemochromatosis with elevated transferrin saturation to our centre between 2005 and 2016, we identified 10 patients with HJV related hemochromatosis. Five HJV variants were previously published and five are new pathogenic variants. Clinical expression was diverse, varying from few symptoms to full blown picture with multiple organ damages.

As reported in previous studies, the p.Gly320Val variant was the most frequent in our patients. Their phenotype was consistent and did not differ from patients with other variants. No correlation between the types of variant and clinical nor biological features was found, due to the number of different variants and the variability of phenotype.

Five new variants in HJV were identified in our patients. Phenotype suggested a deleterious impact of these variants in all cases. For 4 of these variants, family studies confirmed the heterozygous compound state as variants were located in trans. According to the new ACMG guidelines, two of these variants ( $p$.Arg41Pro and p.Lys299Glu) are of uncertain significance whereas three of them (p.His180Arg, p.Ala384Val and p.Cys361Arg) are likely pathogenic.

The variants in the N-terminal half of the protein impairs HJV-BMP6 binding, whereas those in the Cterminal part seem to prevent HJV secretion and its cleavage by TMPRSS6 $(24,25)$. The Arginine residues 41,176 and 288 are important for the protein activity as their mutation decreases HJV membrane expression (26). However, unlike $\operatorname{Arg}^{176}$ and $\mathrm{Arg}^{288}$ that are involved in HJV autoproteolysis, the variant p.Arg41Ala does not seem to have an impact on this process, although the reduced membrane expression could explain the milder phenotype observed in patient 2 . Nevertheless, the Arginine to Proline variation discovered in our patient may impair the bone structure of the protein and prevent BMP-binding.

The newly found variant p.His180Arg affects a residue that forms an aromatic cage that stabilizes the highly conserved $\mathrm{Arg}^{176}$. (26) This role of $\mathrm{His}^{180}$ may explain why a variation could decrease HJV efficiency.

Although the HJV protein is folded due to four disulfide bonds, the $\mathrm{Cys}^{361}$ (that corresponds to the $\mathrm{Cys}^{354}$ on the mouse protein) isn't involved in one of them. (27) Nevertheless, population, computational and allelic data allow us to classify the p.Cys361Arg as a likely pathogenic variant. Similarly the p.Lys299Glu and p.Ala384Val variants whose positions has not been investigated in functional studies, have convergent arguments to classify them as uncertain significance and likely pathogenic respectively.

The notable peculiarity of our study is the late age of onset in some patients, contrasting with the diagnosis of "juvenile" hemochromatosis. Five of our patients were 30 years old or older, including two very late discoveries, at 53 and 60 years old (patient 2 and 7). However biological features and severity of iron overload was similar in younger and older patients.

Reasons for this potential late expression are not obvious and do not seem to be linked to the type of variant. In the study by Koyama et al., variants in HJV were identified in the homozygous state in patients aged 48 and 51 with a phenotype similar to that of our patients. (19). In our study, both 
patients 2 and 7 were compound heterozygous, respectively p.Arg41Pro/p.Arg176Cys and p.Leu101Pro/p.Ala384Val. The p.Arg176Cys variant had previously been described at a homozygous state in a 17-years old patient (28) and at a heterozygous state associated with the p.Gly320Val in a 5 -years old patient (10). In the first description of the p.Leu101Pro variant, homozygous patients were aged from 8 to 23 years old (8). The p.Arg41Pro and p.Ala384Val were newly described variants which putative lower pathogenicity may explain this lower expressivity, although it may also be due to other genetic or environmental factors.

This variable age of onset and severity of HJV hemochromatosis is similar to the previously described variable expressivity of HFE (15) or TFR2 (16) related hemochromatosis. Of note their suggested interaction in the same signaling cascade at the cell membrane $(2,29)$ could explain similar susceptibility to modifying factor eventually leading to hepcidin deficiency. Thereby, patient 9 who had the highest serum ferritin was compound heterozygous p.Cys282Tyr/p.His63Asp in HFE which could have contributed to enhance the expression of disease.

In conclusion, our study shed new light on HJV hemochromatosis and suggests that although its clinical expression is often typical, milder phenotype and late onset are possible. Thus, genetic testing for HJV variants should not be restricted to young patients or severe iron overload and should be proposed in all cases of non p.Cys282Tyr HFE hemochromatosis with hepcidin deficiency phenotype.

\section{AKNOWLEDGEMENTS}

$H H R, Z B A, L D$ and EBJ gathered and analyzed the data and wrote the manuscript. HHR and VD performed the genetic testing. MR performed the biochemical testing. SA, DS, GP and YD included the patient and gathered the data. All authors critically reviewed the manuscript. 
1. Papanikolaou G, Samuels ME, Ludwig EH, MacDonald ML, Franchini PL, Dube MP, et al. Mutations in HFE2 cause iron overload in chromosome 1q-linked juvenile hemochromatosis. Nature genetics. 2004;36(1):77-82.

2. Latour C, Besson-Fournier C, Gourbeyre O, Meynard D, Roth MP, Coppin H. Deletion of BMP6 worsens the phenotype of HJV-deficient mice and attenuates hepcidin levels reached after LPS challenge. Blood. 2017;130(21):2339-43.

3. Filali M, Le Jeunne C, Durand E, Grinda JM, Roetto A, Daraio F, et al. Juvenile hemochromatosis HJV-related revealed by cardiogenic shock. Blood cells, molecules \& diseases. 2004;33(2):120-4.

4. Cherfane C, Lee P, Guerin L, Brown K. A late presentation of a fatal disease: juvenile hemochromatosis. Case reports in medicine. 2013;2013:875093.

5. Lamon JM, Marynick SP, Roseblatt R, Donnelly S. Idiopathic hemochromatosis in a young female. A case study and review of the syndrome in young people. Gastroenterology. 1979;76(1):178-83.

6. Cazzola M, Cerani P, Rovati A, lannone A, Claudiani G, Bergamaschi G. Juvenile genetic hemochromatosis is clinically and genetically distinct from the classical HLA-related disorder. Blood. 1998;92(8):2979-81.

7. Lanzara C, Roetto A, Daraio F, Rivard S, Ficarella R, Simard H, et al. Spectrum of hemojuvelin gene mutations in 1q-linked juvenile hemochromatosis. Blood. 2004;103(11):4317-21.

8. Lee PL, Beutler E, Rao SV, Barton JC. Genetic abnormalities and juvenile hemochromatosis: mutations of the HJV gene encoding hemojuvelin. Blood. 2004;103(12):4669-71.

9. Walker NA, Crawford DH, Subramaniam VN, Wallace DF. Juvenile iron overload--advances, but no answers. J Pediatr. 2008;153(4):588.

10. Aguilar-Martinez $\mathrm{P}$, Lok CY, Cunat S, Cadet E, Robson K, Rochette J. Juvenile hemochromatosis caused by a novel combination of hemojuvelin G320V/R176C mutations in a 5year old girl. Haematologica. 2007;92(3):421-2.

11. Core AB, Canali S, Babitt JL. Hemojuvelin and bone morphogenetic protein (BMP) signaling in iron homeostasis. Frontiers in pharmacology. 2014;5:104.

12. Santos PC, Dinardo CL, Cancado RD, Schettert IT, Krieger JE, Pereira AC. Non-HFE hemochromatosis. Rev Bras Hematol Hemoter. 2012;34(4):311-6.

13. Wallace DF, Subramaniam VN. Non-HFE haemochromatosis. World journal of gastroenterology : WJG. 2007;13(35):4690-8.

14. Bardou-Jacquet E, Brissot P. Diagnostic evaluation of hereditary hemochromatosis (HFE and non-HFE). Hematology/oncology clinics of North America. 2014;28(4):625-35, v.

15. Allen KJ, Gurrin LC, Constantine CC, Osborne NJ, Delatycki MB, Nicoll AJ, et al. Iron-overloadrelated disease in HFE hereditary hemochromatosis. The New England journal of medicine. 2008;358(3):221-30.

16. Bardou-Jacquet E, Cunat S, Beaumont-Epinette MP, Kannengiesser C, Causse X, Sauvion S, et al. Variable age of onset and clinical severity in transferrin receptor 2 related haemochromatosis: novel observations. British journal of haematology. 2013;162(2):278-81.

17. Hamdi-Roze H, Beaumont-Epinette MP, Ben Ali Z, Le Lan C, Loustaud-Ratti V, Causse X, et al. Rare HFE variants are the most frequent cause of hemochromatosis in non-c282y homozygous patients with hemochromatosis. American journal of hematology. 2016;91(12):1202-5.

18. Le Lan C, Mosser A, Ropert M, Detivaud L, Loustaud-Ratti V, Vital-Durand D, et al. Sex and acquired cofactors determine phenotypes of ferroportin disease. Gastroenterology. 2011;140(4):1199-207 e1-2.

19. Koyama C, Hayashi H, Wakusawa S, Ueno T, Yano M, Katano Y, et al. Three patients with middle-age-onset hemochromatosis caused by novel mutations in the hemojuvelin gene. J Hepatol. 2005;43(4):740-2. 
20. Project NGES. Exome Variant Server Seattle, WA2016 [Available from: http://evs.gs.washington.edu/EVS/.

21. Genomes Project C, Auton A, Brooks LD, Durbin RM, Garrison EP, Kang HM, et al. A global reference for human genetic variation. Nature. 2015;526(7571):68-74.

22. Lek M, Karczewski KJ, Minikel EV, Samocha KE, Banks E, Fennell T, et al. Analysis of proteincoding genetic variation in 60,706 humans. Nature. 2016;536(7616):285-91.

23. Richards S, Aziz N, Bale S, Bick D, Das S, Gastier-Foster J, et al. Standards and guidelines for the interpretation of sequence variants: a joint consensus recommendation of the American College of Medical Genetics and Genomics and the Association for Molecular Pathology. Genet Med. 2015;17(5):405-24.

24. Healey EG, Bishop B, Elegheert J, Bell CH, Padilla-Parra S, Siebold C. Repulsive guidance molecule is a structural bridge between neogenin and bone morphogenetic protein. Nat Struct Mol Biol. 2015;22(6):458-65.

25. Pagani A, Silvestri L, Nai A, Camaschella C. Hemojuvelin N-terminal mutants reach the plasma membrane but do not activate the hepcidin response. Haematologica. 2008;93(10):1466-72.

26. Rausa M, Ghitti M, Pagani A, Nai A, Campanella A, Musco G, et al. Identification of TMPRSS6 cleavage sites of hemojuvelin. J Cell Mol Med. 2015;19(4):879-88.

27. Nili M, David L, Elferich J, Shinde U, Rotwein P. Proteomic analysis and molecular modelling characterize the iron-regulatory protein haemojuvelin/repulsive guidance molecule c. The Biochemical journal. 2013;452(1):87-95.

28. Ka C, Le Gac G, Letocart E, Gourlaouen I, Martin B, Ferec C. Phenotypic and functional data confirm causality of the recently identified hemojuvelin p.r176c missense mutation. Haematologica. 2007;92(9):1262-3.

29. D'Alessio F, Hentze MW, Muckenthaler MU. The hemochromatosis proteins HFE, TfR2, and HJV form a membrane-associated protein complex for hepcidin regulation. J Hepatol. 2012;57(5):1052-60.

30. Zhou X, Edmonson MN, Wilkinson MR, Patel A, Wu G, Liu $Y$, et al. Exploring genomic alteration in pediatric cancer using ProteinPaint. Nature genetics. 2015;48(1):4-6.

Figure 1 legend: Distribution of the variants found in our cohort. Five variants have already been published (upper line) but the five others have been newly identified in our cohort, always at a heterozygous state associated with a known alteration. These variants seem to be evenly distributed on the protein. Construction was made using ProteinPaint. (30) 
Table 1: clinical and biological features

\begin{tabular}{|c|c|c|c|c|c|c|c|c|c|}
\hline $\mathrm{N}^{\circ}$ & $\begin{array}{l}\text { Sex, age } \\
\text { and } \\
\text { ethnic } \\
\text { origin }\end{array}$ & Clinical signs & $\begin{array}{l}\text { Ferritin } \\
(\mathrm{ng} / \mathrm{ml})\end{array}$ & $\begin{array}{l}\mathrm{Tf} \\
\text { sat } \\
(\%)\end{array}$ & $\begin{array}{c}\text { Hepcidin } \\
(\mathrm{nmol} / \mathrm{l})\end{array}$ & $\begin{array}{l}\text { Liver } \\
\text { iron } \\
\text { Content } \\
\text { (MRI) } \\
\text { (normal } \\
\text { range: } \\
<36 \\
\mu \mathrm{mol} / \mathrm{g} \text { ) }\end{array}$ & $\begin{array}{l}\text { Liver } \\
\text { biopsy }\end{array}$ & $H J V$ variants & $\begin{array}{c}\text { Variant } \\
\text { classification }\end{array}$ \\
\hline 1 & $\begin{array}{c}\text { M, 28 } \\
\text { Caucasian }\end{array}$ & Hypogonadism & 3300 & 58 & & 350 & & $\begin{array}{c}\text { p.Gly320Val } \\
(\mathrm{c} .959 \mathrm{G}>\mathrm{T}) \\
+/+\end{array}$ & Pathogenic \\
\hline 2 & $\begin{array}{c}\mathrm{M}, 53 \\
\text { Caucasian }\end{array}$ & $\begin{array}{c}\text { Arthralgia } \\
\text { Skin } \\
\text { hyperpigmentation }\end{array}$ & 4220 & 86 & & & $\begin{array}{c}\text { Massive } \\
\text { iron } \\
\text { overload, } \\
\text { cirrhosis }\end{array}$ & $\begin{array}{c}\text { p.Arg41Pro } \\
(\text { c.122G }>\text { C) } \\
+/- \\
\\
\text { p.Arg176Cys } \\
(\text { c. } 526 \mathrm{C}>\mathrm{T}) \\
+/- \\
\end{array}$ & $\begin{array}{c}\text { Uncertain } \\
\text { significance } \\
\text { Pathogenic }\end{array}$ \\
\hline 3 & $\begin{array}{c}\mathrm{F}, 27 \\
\text { Caucasian }\end{array}$ & $\begin{array}{c}\text { Cardiac failure } \\
\text { Diabetes } \\
\text { Secondary } \\
\text { amenorrhea } \\
\text { Severe } \\
\text { Arthropathy } \\
\text { Skin } \\
\text { hyperpigmentation }\end{array}$ & & 85 & 1.6 & & $\begin{array}{c}\text { Iron } \\
\text { deposits, } \\
\text { no } \\
\text { fibrosis }\end{array}$ & $\begin{array}{c}\text { p.Leu101Pro } \\
(\text { c.302T }>C) \\
+/- \\
\\
\text { p.Lys299Glu } \\
(\text { c.895 A }>\text { G) } \\
+/-\end{array}$ & $\begin{array}{l}\text { Pathogenic } \\
\text { Uncertain } \\
\text { significance }\end{array}$ \\
\hline 4 & $\begin{array}{c}\mathrm{M}, 31 \\
\text { Caucasian }\end{array}$ & & 3700 & 91 & & & $\begin{array}{l}\text { Important } \\
\text { iron } \\
\text { overload, } \\
\text { severe } \\
\text { fibrosis } \\
\end{array}$ & $\begin{array}{c}\text { p.Gly320Val } \\
(\text { c. } 959 \mathrm{G}>\mathrm{T}) \\
+/+\end{array}$ & Pathogenic \\
\hline 5 & $\begin{array}{c}\text { M, } 8 \\
\text { North } \\
\text { African }\end{array}$ & Asthenia & 282 & 83 & 0.7 & 190 & & $\begin{array}{c}\text { p.Arg385X } \\
(\mathrm{c} .1153 \mathrm{C}>\mathrm{T}) \\
+/+\end{array}$ & Pathogenic \\
\hline 6 & $\begin{array}{c}\mathrm{M}, 31 \\
\text { Caucasian }\end{array}$ & Arthralgia & 2300 & 100 & & & $\begin{array}{c}\text { Iron } \\
\text { overload } \\
433 \\
\mu \mathrm{mol} / \mathrm{g}\end{array}$ & $\begin{array}{c}\text { p.Leu101Pro } \\
(\text { c. } 302 \mathrm{~T}>\mathrm{C}) \\
+/- \\
\\
\text { p.His180Arg } \\
\left(\begin{array}{c}\text { c.539A }>\mathrm{G}) \\
+/-\end{array}\right.\end{array}$ & $\begin{array}{c}\text { Pathogenic } \\
\text { Likely } \\
\text { pathogenic }\end{array}$ \\
\hline 7 & $\begin{array}{c}\mathrm{F}, 60 \\
\text { Caucasian }\end{array}$ & $\begin{array}{c}\text { Asthenia } \\
\text { Diabetes } \\
\text { Skin } \\
\text { hyperpigmentation } \\
\end{array}$ & 4800 & 86 & 1.1 & 340 & & $\begin{array}{c}\text { p.Leu101Pro } \\
(\text { c.302T }>C) \\
+/- \\
\\
\text { p.Ala384Val } \\
(\text { c.1151 C>T) } \\
+/- \\
\end{array}$ & $\begin{array}{c}\text { Pathogenic } \\
\text { Likely } \\
\text { pathogenic }\end{array}$ \\
\hline 8 & $\begin{array}{c}\text { M, 32 } \\
\text { Caucasian }\end{array}$ & Hypogonadism & 4959 & 90 & & 350 & & $\begin{array}{c}\text { p.Arg288Trp } \\
\text { (c.862 C }>\mathrm{T}) \\
+/+ \\
\end{array}$ & $\begin{array}{c}\text { Likely } \\
\text { pathogenic }\end{array}$ \\
\hline 9 & $\begin{array}{c}\text { F, 30 } \\
\text { Caucasian }\end{array}$ & $\begin{array}{c}\text { Secondary } \\
\text { amenorrhea } \\
\text { Arthralgia } \\
\text { Atrial fibrillation }\end{array}$ & 7137 & 100 & & $\begin{array}{l}\text { Massive } \\
\text { overload }\end{array}$ & $\begin{array}{l}\text { Massive } \\
\text { iron } \\
\text { overload, } \\
\text { cirrhosis }\end{array}$ & $\begin{array}{c}\text { p.Gly320Val } \\
\text { (c.959G }>\text { T) } \\
+/- \\
\\
\text { p.Cys361Arg } \\
(\text { c.1081T>C) } \\
+/- \\
\end{array}$ & $\begin{array}{c}\text { Pathogenic } \\
\text { Likely } \\
\text { pathogenic }\end{array}$ \\
\hline 10 & $\begin{array}{c}\text { F, } 16 \\
\text { Caucasian }\end{array}$ & $\begin{array}{c}\text { Asthenia } \\
\text { Hypogonadism } \\
\text { Skin } \\
\text { hyperpigmentation }\end{array}$ & 2270 & 89 & & 300 & & $\begin{array}{c}\text { p.Gly320Val } \\
(\mathrm{c} .959 \mathrm{G}>\mathrm{T}) \\
+/+\end{array}$ & Pathogenic \\
\hline
\end{tabular}




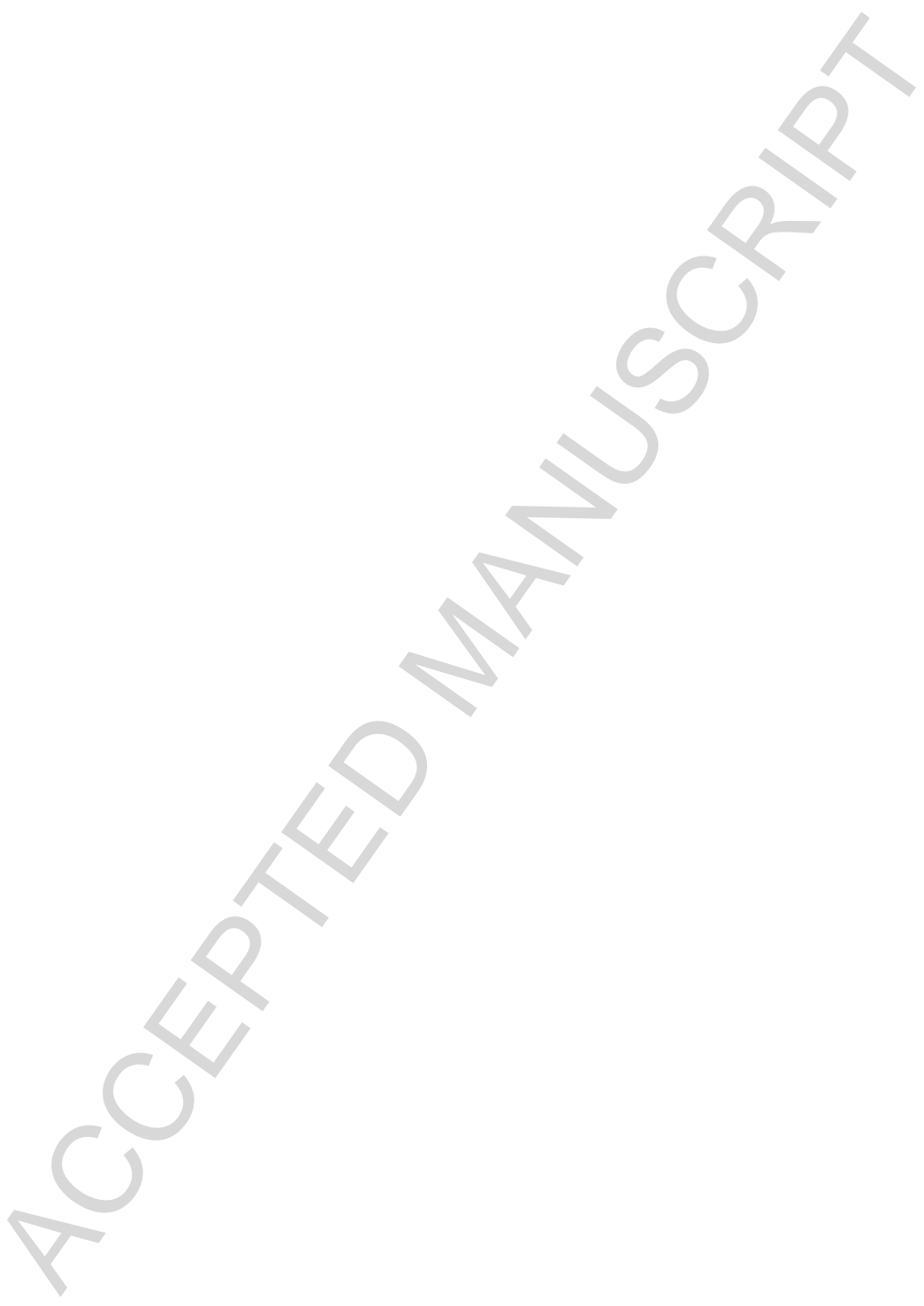


Already described variants

HFE2

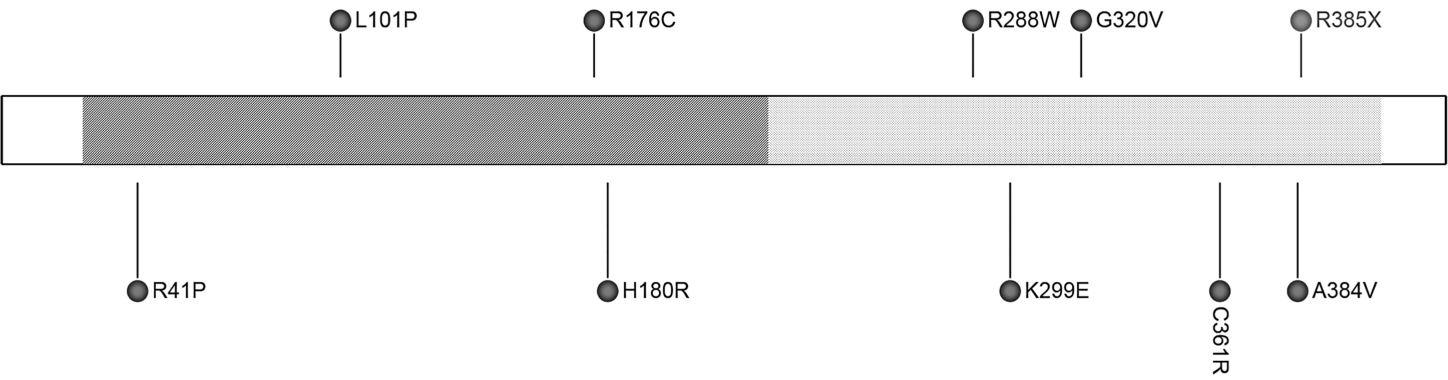

R288W

G320V

R385X

Newly found variants 